\title{
Christian Dress Code during Online Worship
}

\author{
Nurmalia Pardede $^{1 *}$, Evinta Hotmarlina ${ }^{2}$, Garry Kurniawan ${ }^{3}$, David Kristanto ${ }^{4}$ \\ 1, 2, 3 Sekolah Tinggi Teologi Internasional Harvest, Tangerang, Indonesia \\ ${ }^{4}$ Sekolah Tinggi Teologi Injili Arastamar (SETIA) Jakarta, Indonesia \\ *Corresponding author. Email: nurmaliapardede@gmail.com
}

\begin{abstract}
Churches in Indonesia have been conducting online worship for more than a year (2020-2021). Research done by Indonesia Preaching Ministry has shown that only around $20 \%$ of the church members faithfully follow the worship service from beginning to end. Christian attitude while attending online worship is also problematic. Some Christians are cooking, and others are lying on their bed while attending online worship. Another problem is the dressing code for Christians who attend online worship. How should Christians dress themselves during online worship would be the research question of this article. This article uses exegetical theology as a research method. And the main argument of this paper is that, while the Bible sufficiently attends to the dressing code of the people of God (Deut. 22:5; Ezek. 44:17; 1 Cor. 11:6; 1 Tim. 2:9-10; 1 Pet. 3:3-5); 1 Cor. 11:4-7 could be the most relevant starting point for ethical-theological discussions on the matter. It exhorts Christians to dress appropriately not just for the sake of others but as an expression of honoring God when participating in worship. Toward that goal, this paper will be written under this sequence: first, it will present the context of the Corinthian church; second, it will elaborate the interpretation of 1 Cor. 11:4-7; third, it will seek to apply 1 Cor. 11:4-7 to the present context; then conclude.
\end{abstract}

Keywords: Christian Dress Code, Christian Ethics, Exegetical Theology, Online Worship

\section{INTRODUCTION}

The church could not gather physically to worship during the pandemic due to the social or physical distancing policy. That situation leads the church leaders to choose technology as the alternative, thus conducting the worship service online. Christians believe that technology is a blessing from God, for it enables the church to worship even amid the pandemic. However, there is also research that shows the negative effect of online worship. Indonesia Preaching Ministry presents the data that only around $20 \%$ of the congregation follows the worship from the beginning to the end during online worship. The attitude of the congregation while attending the online worship is also many times inappropriate. Some people do some other activities while attending online worship, and others dress improperly while worshipping online [1].

Some churches, such as the Roman Catholic Church and Gereja Bethel Tabernakel Alfa Omega Yesus Penolong, have guided the congregations' dressing ethics while worshipping online. Those two churches have exhorted their congregations to prepare themselves with the proper and honorable way of dressing, and there is also an exhortation to not lay on the bed or doing other activities while participating in online worship [2].

Even though some churches have started to pay attention to the dress code of their congregations while attending online worship, there are still many churches that are yet to pay sufficient attention to the matter. Theological articles in Indonesia and abroad that address the matter are also relatively few. The fact that many churches did not address the matter after a year of worshipping online indicates that they did not see the urgency of the matter.

That is not the case with the Bible. The Bible addresses the dressing ethics of God's people quite frequent. For example, Deut. 22:5; Ez. 44:17; 1 Cor. 11:6; 1 Tim. 2:9-10; 1 Pet. 3:3-5; and many more. Some of those references address dressing ethics generally, but some references address dressing ethics as specifically related to worship, such as 1 Cor. 11:4-7. Thus, this article argues that 1 Cor. 11:4-7 could be the starting point to discuss dressing ethics theologically while participating in online worship. Worship should express the fear of the Lord and an act of honoring God, and that should be done as well through the way of dressing. 
Toward that purpose, this article will first deal with the context of worship in the Corinthian church; second, the exposition of 1 Cor. 11:4-7; third, the implication of 1 Cor. 11:4-7 to the contemporary situation; then conclude.

\section{RESEARCH METHOD}

This article will use biblical exegesis as the research method. Smith defines biblical exegesis as a resounding, "inductive examination of Scripture," that attempts to exegete the biblical text systematically using hermeneutical methods so the text's meaning and implications could be discovered [3, p. 131]. This article attempts to analyze 1 Cor. 11:4-7 and its relevance to the dressing ethics while participating in online worship. Toward that purpose, this article will first analyze the context of the Corinthian church; second, the interpretation of 1 Cor. 11:4-7; and third, the application of 1 Cor. 11:4-7 to the context of online worship now; and fourth, conclude.

\section{RESULTS AND DISCUSSION}

\subsection{The Context of the Corinthian Church}

The city of Corinth was a center of trade, famous for luxurious stuff that had a high value of art. The wealth of the city of Corinth had made it one of the most prominent cities in ancient Greek. In terms of morality, the people of Corinth were well-known for their immorality, especially sexual immorality. Prostitution there was famous not just for pleasure per se but also for religious motives. The city was known for thousands of sacred prostitutes throughout all the temples that existed in that city [4, p. 775-6]. This situation made it necessary for Paul to plant a church there, to serve the people with the Christian ministry.

The Corinthian congregation was by no means perfect in their morality as well. The city also influenced them, and since they were not familiar with Judaism, they were not accustomed to the Jewish religious discipline; thus, even after becoming Christians, they still lacked spiritual maturity. The Corinthian church needed the apostles' teaching ministry more than other Christians who were familiar with the spiritual discipline of Judaism [5, p. 365].

Some major problems of the Corinthian church are as follow: first, the problem of division. Some people in the congregation identify themselves as a group belonging to Paul, others to Apollos and Peter [6, p. 522]. This division happened because of their envy and quarrels. The feeling of superiority of a particular group against other groups was intense. Paul warned them that they should not be like a worldly human who did not understand God's will and how they belong to no one but Christ alone; second, there is also a problem related to legal matters. Paul advised them not to seek justice in the Roman court but to work out the solution with the leadership of the church of Corinth [7]; third, there was a problem of sexual impurity between a step-child with a step-mother. That is considered adultery for the stepchild who took the wife of his father as his [7]; fourth, a problem related to eating the food that had been presented to other gods. Paul forbade it because by doing that, the person had associated himself or herself in fellowship with the evil spirits [8]; fifth, the problem of dressing ethics during the worship service (1 Cor. 11). This problem will be addressed in more detail, for it is the main topic of this article.

\subsection{Interpreting 1 Corinthians 11:4-7}

In 1 Cor. 11:4-7, Paul deals with the issue of head covering in the context of worship at the Corinthian Church. Head covering here refers to something that distinguishes man from the woman in worship. That implies that the dressing ethics of man and woman during worship was different at that time. The man should not wear woman's dressing nor vice versa. That kind of thing does not comply with God's will, and that is a thing that is wicked in God's eyes (Deut. 22:5) [9, p. 54].

There is evidence that Roman men usually cover their heads while offering sacrifices to their gods, but the Jewish men usually worship without covering their heads. So, the allusion of the practice in verse 4 is perhaps due to the Jewish dressing code while worshipping. In contrast with that, the first-century Jewish women were usually worshipping by covering their heads. Verses 4 and 5 clearly show the distinction between male and female dressing codes while worshipping. However, it is essential to note that both come to the presence of God in equality. The expression "woman is the glory of man" in verse 7 should be taken as women are inferior to men; rather it should be seen as Paul's view of how every wife expresses in a unique way, "the excellence of her husband." [10, p. 2031].

For Paul, men and women are equal just as Father and Christ Jesus are equal in "worth, excellence, and dignity." Moreover, men and women could share their faith in equality before the presence of God. The main principle is clear that the difference between male and female should be maintained and expressed in a different way of dressing, even though that distinction by no means downplay equality between them [11, pp. 402-3].

According to Craig Keener, the issue of head covering in worship refers to a distinction between male 
and female and a distinction among female church members. In the first century context, it was common for women to cover their heads in Judea; some more conservatives were even covering their faces with a veil. However, some upper-class Roman women liked to show off their fashionable hairstyle. Thus, they did not usually cover their heads. There is a good reason to believe that Paul addresses the culture clash between the upper and lower-class women in the Corinthian church when discussing the head covering in 1 Cor. 11:4-7 [12, p. 482].

\subsection{Applying 1 Corinthians 11:4-7 to Online Worship Now}

When considering the dressing code in worship, both the horizontal aspect (between one and other church members) and the vertical aspect (between one and God) should be addressed sufficiently. In the context of online worship, people often neglect the responsibility of dressing ethically or with propriety because no other person will be looking at their dressing. That way of reasoning emphasizes the horizontal aspect of the matter while completely neglecting the vertical aspect. Whoever worships should ask whether her or his dressing glorifies or offends God. The horizontal aspect is also crucial. One should not neglect the proper way of dressing when worshipping because it could be a stumbling block to others. There is no such thing as neutral when living communally in a church community; one thing could be either a blessing for others or a stumbling block. When one fails to be a blessing for others through the improper way of dressing during worship, that person fails to glorify God through worship [13, p. 120].

The dressing ethics in 1 Cor. 11:4-7 is related to the issue of gender and equality. However, the importance of dressing ethics there should not be overlooked due to the two issues. Paul maintains that the distinction and equality between males and females should be expressed in dressing while worshiping. This instruction is also an issue of equality between lower and upper-class women of that time. By instructing women to cover their heads, there would be no class distinction between the two, but only maintaining male-female distinction that originated from the creation order. This instruction shows that while worshipping, everybody is equal before the presence of God, as males and females are created in equality.

This instruction of covering the head played an essential role in the first-century Corinthian church to distinguish men from women. However, it is crucial to note that this is not a universal instruction. Women do not have to cover their heads in societies that do not see head covering as a distinguishing feature between men and women [14, p. 460]. Dressing ethics has never been culture-free perspectives. If one is to apply 1 Cor. 11:4-7 to the context of online worship now, one should ask about what kind of dressing is considered proper these days. Furthermore, most importantly, one should ask herself or himself how could the way of dressing lead to God's glory and edifying others instead of offending the presence of God or other church members while worshiping.

\section{CONCLUSION}

One of the critical challenges that the church should face while conducting online worship is to question the dressing code of its members while participating in worship. The way of dressing could be glorifying or offending God and could also be edifying to other church members or becoming a stumbling block for others. The issue of head covering in the worship context is central to the understanding of 1 Cor. 11:4-7. It maintains differences between the dressing code of men and women while not eradicating the equality in the original creation order between the two. Furthermore, it also maintains equality between upper and lower-class women of that time. By covering the head, the economic or class distinction between the more affluent and poorer women would be no more, but there would only be a distinction between male and female, as God created them in equality before His presence.

\section{REFERENCES}

[1] M. Harmadi and A. D. Budiatman, "Pergeseran Perspektif Teologi Penggembalaan Dengan Layanan Virtual Pada Masa Pandemi Sekarang dan Nanti," Jurnal Teologi Berita Hidup, vol. 3, no. 2, pp. 137-149, 2021.

[2] B. R. Hutagalung, "EKSEGESIS 1 KORINTUS 11:2-16 DAN IMPLIKASINYA TERHADAP ETIKA BERBUSANA DALAM IBADAH DARING DI MASA PANDEMI COVID-19,' Voice of Wesley: Jurnal Ilmiah Musik dan Agama, vol. 4, no. 1, pp. 67-81, Feb. 2021.

[3] K. G. Smith, Writing and Research: A Guide for Theological Students. UK: Langham Global Library, 2016.

[4] C. F. Pfeifer and E. F. Harison, Eds., Tafsiran Alkitab Wycliffe Vol. III. Malang: Gandum Mas, 2013.

[5] M. C. Tenney, Survei Perjanjian Baru. Malang: Gandum Mas, 2017.

[6] L. Ryken, J. C. Wilhoit, and T. L. III, Kamus Gambaran Alkitab. Surabaya: Momentum, 2011.

[7] P. W. Yahya, "Tubuh adalah Bagi Tuhan: Sebuah 
Tinjauan Eksegesis 1 Korintus 6:12-20," Veritas: Jurnal Teologi dan Pelayanan, vol. 14, no. 2, pp. 233-252, Oct. 2013.

[8] E. C. Wijaya and W. Laksana, "TINJAUAN TEOLOGIS PRAKTIK MAKAN MAKANAN YANG DIPERSEMBAHKAN BERHALADALAM HIDUP ORANG PERCAYA DI INDONESIA," Logia: Jurnal Teologi Pentakosta, vol. 2, no. 2, pp. 89-102, 2021.

[9] S. Eveline, "Transgender dalam Perspektif Teologis Alkitabiah," Kaluteros: Jurnal Teologi dan Pendidikan Kristen, vol. 1, no. 1, pp. 54-61, 2019.

[10] R. C. Sproul, Ed., The Reformation Study Bible. Orlando: Reformation Trust, 2015.

[11] T. R. Schreiner, Paul, Apostle of God's Glory in Christ: A Pauline Theology. Westmont: IVP Academic, 2006.

[12] C. S. Keener, IVP Bible Background Commentary: New Testament. Downers Grove: InterVarsity Press, 2014.

[13] I. W. Purnama and S. A. Tarigan, "Tinjauan Etika Kristen Terhadap Operasi Transeksual," Jurnal Jaffray, vol. 9, no. 1, p. 109, Apr. 2011.

[14] W. A. Grudem, Systematic Theology: An Introduction to Biblical Doctrine. Grand Rapids: IVP Press, 2004. 